Portland State University

PDXScholar

5-24-2019

\title{
Mexico's Newest Threat: Cártel de Jalisco Nueva Generación (CJNG)
}

Maria Teresa Olivares

Portland State University

Follow this and additional works at: https://pdxscholar.library.pdx.edu/honorstheses Let us know how access to this document benefits you.

\section{Recommended Citation}

Olivares, Maria Teresa, "Mexico's Newest Threat: Cártel de Jalisco Nueva Generación (CJNG)" (2019). University Honors Theses. Paper 726.

https://doi.org/10.15760/honors.744

This Thesis is brought to you for free and open access. It has been accepted for inclusion in University Honors Theses by an authorized administrator of PDXScholar. Please contact us if we can make this document more accessible: pdxscholar@pdx.edu. 
Mexico's Newest Threat: Cártel de Jalisco Nueva Generación (CJNG)

by

Maria Teresa Olivares

An undergraduate honors thesis submitted in partial fulfillment of the requirements for the degree of

Bachelor of Arts

in

University Honors

and

International \& Global Studies: Latin America

Thesis Adviser:

Dr. Shawn Smallman

Portland State University

Spring 2019 


\begin{abstract}
Lessons from history in the Mexican Drug War demonstrate that the kingpin strategy, a model developed by the Colombian government in the 1980s to capture or kill cartel leaders, has led to failure for Mexico in its drug war. Because of the significant reduction in violent crime in Colombia, many policymakers have pointed to Colombia's case as an example for Mexico. This idea, however, is concerning because the contexts in both countries differ. Therefore, the kingpin strategy should not be implemented to capture or kill the leader of the Cártel de Jalisco Nueva Generación (CJNG), Nemesio Oseguera Cervantes, alias"El Mencho," because the differences in the two nation's context suggest that this approach will not adequately address the insecurity and violence that Mexico struggles with. The kingpin strategy has created a cycle in which it promotes violence rather than reducing it, and leads to the destabilization or fragmentation of an organization and the emergence of dangerous new organizations.

This thesis asks how have the military intervention strategies of the Mexican government like the "Kingpin Strategy" and "Operation Jalisco" been overcome by the Cártel de Jalisco Nueva Generación? I demonstrate the failures of the Mexican government, with aid from the U.S. government, to dismantle its cartels. At the same time, I identify the critical factors to the CJNG's success in adapting and maintaining its position in the ever-changing environment of Mexico's drug trade. With that, I argue that Colombia's model of the "Kingpin Strategy" cannot be exactly replicated nor should Mexico continue to use in its case because there are several reasons to be concerned of the comparison to the Colombian case. Mexico's long history has demonstrated that this model will ultimately fail.
\end{abstract}




\section{Violence Strikes Jalisco: The CJNG Makes its Mark}

Six Mexican military officials were killed on May 2015 after members of the Cártel de Jalisco Nueva Generación (CJNG) shot down a Eurocopter EC725 helicopter with a rocket-propelled grenade. Making its mark, the CJNG committed one of the boldest acts of violence in the Mexican Drug War, demonstrating that it will defy the government with spectacular attacks on security forces. National Security Commissioner Monte Alejandro Rubido declared, "The fact that they attacked a Cougar helicopter with rockets... demonstrates the firepower of this group" (Thomet, 2015). The attack quickly came as the Mexican government announced the launch of Operación Jalisco (Operation Jalisco), an effort aiming to restore security to Jalisco by dismantling the CJNG's influence and power. Because of the objectives and militarized operation, this operation can indeed be seen closely related to the kingpin strategy. Besides shooting down the helicopter, the CJNG coordinated approximately 39 attacks throughout the state, including in Guadalajara, one of Mexico's main cities by setting fire to banks, gas stations, private shops in the city, and buses blocking highways and bridges (The Global Initiative, 2015). Dozens were injured and 15 were killed in the violence, and despite the CJNG's proclamations about protecting civilians, this event left the population terrorized. According to Rubido, "It's a group that has grown and expanded to other states, such as Colima, Guanajuato, Michoacán, with a presence in Veracruz" (Thomet, 2015).

The CJNG formed in 2010 and has become Mexico's fastest growing and most aggressive organization; the cartel now has a presence in several regions throughout Mexico, while creating an alliance with criminal organizations in the U.S., Europe, and Asia (Beittel, 2018, p. 23). Drug trafficking existed before Mexican drug cartels began dominating the drug trade; therefore, "drug 
trafficking in Mexico is by no means a recent phenomenon" (Bunker, 2015). Many policymakers have compared Mexico's drug war to the Colombian experience (Haugaard, Isacson, \& Johnson, 2011, p. 3). Because of slight resemblances between both countries' situation, experts have suggested that there are essential lessons in Colombia's kingpin strategy model for Mexico to learn from in order to combat its drug cartels. However, Colombia's approach should not be viewed as one that will work for Mexico because there are differences and the circumstances specific to Mexico call for a more distinct approach. If the kingpin strategy were to be implemented against the CJNG, it would fail to target the aspects that have made the CJNG successful and to address Mexico's real problems. This research addresses the question: How have the military intervention strategies of the Mexican government like the "Kingpin Strategy" and "Operation Jalisco" been overcome by the Cártel de Jalisco Nueva Generación?

\section{Methods}

In order to demonstrate the ineffective applicability of Colombia's model to Mexico's situation, a comparative examination will be applied to explore the similarities and differences between both contexts. Furthermore, to understand Mexico's drug war, it is critical to briefly explore the history of how Mexico's major cartels today gained their control over the drug supply chain and explore how the kingpin strategy in Mexico has shown little evidence of avail. This, in turn, will help assess the rise and success of the CJNG and apply a case study of how the CJNG has adapted following the disruption of leadership structures (kingpin strategy), which allows it to overcome the government's militarized approach. While this study includes the activities of other major Mexican cartels, it mainly focuses on one particular cartel: Cártel de Jalisco Nueva Generación (Jalisco Cartel New Generation; the CJNG) because there is extensive media 
coverage on this most recent risen cartel, but limited scholarly attention. Also, the CJNG serves as another critical product of how the kingpin strategy is an ultimate fail and how it is operating better than its rivals to survive and keep its position in the competitive and ever-changing environment of Mexico's drug trade. The goal of this work is to demonstrate the failures of the Mexican and the U.S. government to dismantle the cartels. It will also seek to explain why Colombia's strategy cannot be exactly replicated in Mexico's case because there are several reasons to be concerned about the comparison to the Colombian case. By examining Mexico's situation, new strategies can hopefully be created that accommodates Mexico's specific needs for aid and action.

\section{History: The Fall of Old Cartels and the Rise of New Cartels}

It is critical to have a little history of how Mexico's major cartels today gained their control over the drug supply chain and explore how the kingpin strategy in Mexico has shown little evidence of avail. Drug trafficking existed before Mexican drug cartels began dominating the drug trade. During the 1980s and 1990s, the Colombian government, with U.S. aid, battled with two of its major cartels: the Medellín and Cali cartel. Both cartels dominated all aspects of the international cocaine trade, from wholesale production to transportation, to wholesale distribution in the U.S. and Europe (DEA, 2018). Pablo Emilio Escobar Gaviria, the notorious leader of the Medellín Cartel who was gunned down in 1993, established the cartel's fierce reputation through the use of intimidation and violence to achieve its goals (Chepesiuk, 2003, p. 61). The brothers Gilberto and Miguel Rodríguez-Orejuela, who formed and ran the Cali Cartel, pursued a "low-profile" strategy and the reputation of a less violent and less threatening, criminal enterprise; the Cali Cartel believed they should buy the Colombian government rather than 
killings and terrorize it (Chepesiuk, 2003, p. 68). The Rodríguez-Orejuela brothers were captured in 1995 and later extradited to the U.S. to serve 30-year prison sentences (Kellner \& Pipitone, 2010, p. 29). Because of Colombia and U.S. efforts to reform Colombia's law enforcement strategy to remove these leaders and weaken the cartels, there was a power shift, and their violence capabilities and influence were effectively reduced (Haugaard, Isacson, \& Johnson, 2011, p. 8). This "success" was partial, however, because it failed to reduce the drug supply and resulted in much smaller drug trafficking organizations, which were much reduced in violent capability, and substantially abridged in coercive capacity. Besides, there was little to no change in the production and transportation of illicit narcotics.

On the one hand, there are large-scale Colombian cartels working closely with Mexican cartels to export multi-ton quantities of cocaine out of Colombia each year and on the other hand, there are small-scale Colombian cartels maintaining direct cocaine and heroin pipelines, for small amounts, into the U.S. through couriers on commercial flights and air cargo (DEA, 2018). In short, the Mexican cartels today dominate the role of principal exporters of wholesale distribution of cocaine into U.S. markets, while Colombian cartels maintain control of the supply of cocaine at its source (DEA, 2018). Although the drug war and the drug trafficking did not end, the Colombian and U.S. governments' efforts did limit and helped gain control of the drug trafficking. Colombian cartels do continue to impact the U.S. illicit drug market; however, at a lesser extent than in the 1980s and 1990s (DEA, 2018). In addition, the efforts of the Colombian and U.S. governments created an opening for Mexican organized crime groups, such as the Guadalajara Cartel led by Miguel Ángel Félix Gallardo, alias "El Padrino" ("The Godfather"), and his successors, to seize control of the lucrative North American drug trade. Although 
arrested in 1989, "El Padrino" remained in charge and managed the operations - orchestrating meetings and dividing territory from prison; his arrest, however, did lead to others wanting a piece of the underworld. Therefore, they started developing their drug operations from scratch (Kellner \& Pipitone, 2010, p. 30). This experience demonstrates the failure of the kingpin strategy.

\section{Colombia \& Mexico: Comparative Analysis}

Colombia's model was most effective at reducing the violence and influence of the Medellín and Cali cartels. Nevertheless, this strategy should not be viewed as an approach that can be standardized to combat all criminal organizations. The Mexican problem embodies several distinct differences from the challenges faced by Colombian security forces. Ignoring the differences between the two struggles creates the risk of an ineffective approach that limits any form of tangible success.

\section{Number of Cartels}

One of the differences between Colombia and Mexico's drug war is the number of cartels involved. On the one hand, in Colombia, there were two major cartels - the Medellín and Cali cartels - which its kingpin strategy targeted. On the other hand, Mexico has found itself challenged by numerous cartels (DEA, 2018). It is incredibly challenging for the Mexican to attempt and battle its cartels one by one because it runs into the risk of other cartels taking the opportunity to fight for control of territory and grow and increase its influence. Also, each cartel operates slightly different, which is worth noting that one standardized approach will most likely not succeed; this fact requires that the Mexican government approach its situation on its terms. 


\section{Character of Violence: Targets \& Tactics}

Furthermore, the level of violence differs between both countries' cartels. In Colombia, both cartels avoided extreme measures of extortion and violence directly targeting the local population. In other words, the acts of violence such as kidnappings and murders were maintained with some relation to the drug trade; Colombian cartels were directing their violence against the state, targeting high-profile federal officials, judges, and political figures for kidnappings and/or assassinations (Escalante Gonzalbo, 2009, p. 90). When the leaders were taken out, the threats to the federal government were reduced. However, the majority of the violence was attributed to guerrillas and paramilitaries such as the FARC, ELN, and AUC; the violence was political rather than only being linked to drug trafficking (Escalante, Gonzalbo 2009, p. 91).

In Mexico, violence has been about organized crime. Mexican cartels sustain their wealth and influence through coercive extortion measures aimed at small and big businesses and local populations; when extortion fails, cartels resort to violence as a form of punishment (Haugaard, Isacson, \& Johnson, 2011, p. 3-4; Keefe, 2012). In addition, Mexican cartels have transformed the character of violence by taking it to the next level and using extreme forms of violence such as torture, dismemberment, decapitation, and corporeal inscription; all can arguably be considered as an intentional form of communication and an attempt to terrorize rivals, government officials, and the public. Further, Mexican cartels use specific types of weapons as such AK-style and AR-style rifles, grenades, and use specific tactics on their targets such as assassinations of law enforcement agents, journalists, and street gun battles (Shirk \& Wallman, 2015, p. 1351). Altogether, after Escobar's death, this is a stark contrast to Colombian activities 
that mostly focused all efforts on maximizing profit through drug trafficking operations, rather than mainly focusing on challenging the government.

\section{Geography \& Territory}

The operation and methods of drug trafficking in relation to geography vary. On the one hand, Colombia is not close to the U.S. border. Therefore, it relied heavily on its access to significant coastlines such as the Pacific Ocean and the Caribbean Sea to move illicit drugs into the U.S. This changed in the 1980s as Colombia implemented its militarized anti-trafficking policy (Shirk \& Wallman, 2015, p. 1357). The majority of the cocaine and heroin produced and exported by Colombian cartels to the U.S. began being transported through Central America and Mexico using various transportation methods to include private and commercial aircraft, semi-submersibles, fishing vessels and speedboats (DEA, 2018). Also, Colombia uses its neighboring countries Ecuador and Venezuela as transshipment points for cocaine shipments bound for Mexico, Central America, and the Caribbean (DEA, 2018). Colombia's current contributions to the drug trade demonstrate Colombia's partial "success" in its drug war.

On the other hand, the distance from the U.S. was of no concern to Mexico. Its close proximity, however, led to states adjacent to the Mexico-U.S. border to experience high levels of violence, some for prolonged periods, due to the battles between cartels whose immediate aim is to seize control of key routes into the U.S. (Shirk \& Wallman, 2015, p. 1354; 1357). Furthermore, Mexican cartels transport the majority of illicit drugs into the U.S. across the Southwest border using various smuggling techniques including subterranean tunnels, commercial cargo trains, passenger buses, maritime vessels, backpackers or "mules," and various aerial methods (DEA, 2018; Asmann, 2018). The most commonly used method is to send illicit 
drugs through U.S. ports of entry (POEs) in passenger vehicles with concealed compartments or mixed with legitimate goods on tractor trailers. Altogether, Mexican cartels have managed to assume increased responsibility to plan and execute major drug trafficking operations.

Furthermore, in relation to the financing mechanisms, Mexican cartels have expanded operations into a diversified field of illicit activities such as oil and gas siphoning, extortion, and illegal mining, while the Colombia cartels relied on drug profits and money laundering to finance their respective systems (Chepesiuk, 2003, p. 93; Jones, 2018, p. 26-27). David Shirk and Joel Wallman point out that cartels" "lack recourse to legal remedies to rectify violations of business agreements and to protect against those who would impinge on their activities or prey on their proceeds" (Shirk \& Wallman, 2015, p. 1354; 1350). The diversified field of illicit activities, especially violence, allows cartels to contain any plans aimed at their drug activities and deliver their message: "We are powerful, we are ruthless, you could be next" (Shirk \& Wallman, 2015, p. $1354 ; 1355-1356)$. With that said, Mexican cartels' diversified illicit activities increase the challenge as it creates a more complex situation compared to Colombia's.

\section{Government's ability to respond}

The problems that the Colombian government faced were a result of the lack of governmental presence in rural and low-income urban areas and the decades-long unattended land grab and propriety issues (Haugaard, Isacson, \& Johnson, 2011, p. 10). Colombia's weak democratic government and presence in all of its nation allowed the opening of a power vacuum in which the paramilitaries and guerrilla forces were established. Furthermore, the Colombian government waged a massive and long-standing campaign, which was funded by the U.S. through a strategy known as Plan Colombia (Haugaard, Isacson, \& Johnson, 2011, p. 3). Plan 
Colombia, created in 2000, aimed to crack down on cocaine farms and illegal drug activity that had been going on for decades. Colombia's security forces - the army, navy, air force, and police - were provided with $\$ 860$ million and over the next decade, it would receive an additional three-quarters of $\$ 6.5$ billion (Haugaard, Isacson, \& Johnson, 2011, p. 6). Because of its mixed results and the severe human rights abuses committed by Colombian security forces, according to Haugaard, Isacson, \& Johnson, Plan Colombia has been controversial. Colombia was able to achieve its objective of dismantling its two major cartels, but it failed to reduce the drug supplies.

Further, Mexico's democracy is relatively new and highly vulnerable as it is emerging from 70 years of a single-party rule by the Institutional Revolutionary Party (Partido Revolucionario Institucional - PRI). Years of this strong single-party rule was created through a combination of repression and co-optation; this system was easily caught in corruption by cartels (Haugaard, Isacson, \& Johnson, 2011, p. 10). According to Fernando Escalante Gonzalbo, a professor and researcher at El Colegio de México, when the predominating role was terminated in 2000, no particular mechanism was left to co-opt and control the informal sector (Escalante Gonzalbo, 2009). Unlike Colombia, Mexico deployed soldiers into states where there were high levels of influence to reduce violence. For example, former president Vicente Fox announced his military deployment through Operativo México Seguro (Operation Safe Mexico), former president Felipe Calderón's administration turned to armed forces to battle its cartel, and former president Enrique Peña Nieto sent soldiers to the state of Michoacán in 2013.

Overall, such differences suggest that replicating the Colombian law enforcement model would not adequately address the security situation faced by Mexican forces. Despite these differences, there are several parallels to the Colombian study. Accordingly, policymakers point 
to Colombia's model and suggest that it provides valuable lessons that may be essential to the development of an effective Mexican law enforcement strategy.

The areas in which similarities can be identified include bribery, coercive violence, and the discrediting of authority/corruption.

\section{Bribery, Violence \& Corruption}

With regards to coercive violence, kidnappings, torture, and murder are efforts reflected in both countries. However, it can be argued that Mexico's cartels have taken acts of violence to another level when decapitating and dissolving bodies into acid, coercive acts which exceed the coercive efforts of the Colombian cartels. Further, in regards to bribery and corruption, Colombian cartels bribed security forces at all levels, from low-level to high-level (Haugaard, Isacson, \& Johnson, 2011, p. 11). For instance, the DEA estimated that a low-level Colombian National Police officer would be bribed with $\$ 1,550$ per week, captains bribed with $\$ 5,000$ per week, and generals bribed with $\$ 15,000$ per week (Chepesiuk, 2003, p. 94). These large amounts created a challenging for the Colombian government to battle the Cali Cartel.

Similarly, Mexican cartels annually spend over one billion dollars in bribes of law enforcement and politicians (Lee, Renwick, \& Labrador, 2019).

\section{Operations}

In addition to cartel inputs and activities, there are similarities in the general structure of their respective organizations; operations were in a centralized structure. In the same way, Pablo Escobar controlled every aspect of his cartel's cocaine trade, "El Padrino" maintained strict oversight of the Guadalajara Cartel's narcotics distribution (Shirk \& Wallman, 2015, p. 1357). 
The similarities between both contexts mainly end there. Because of the similarities and the decline in violence, it is tempting, as Lisa Haugaard, Adam Isacson, and Jennifer Johnson put it, for policymakers to suggest replicating or considering Colombia's case to solve Mexico's situation. However, it is clear that those policymakers fail to acknowledge that Colombia's case not only is different compared Mexico's case but also that it was not entirely successful; there was an unintended increase in U.S. drug consumption and distribution and expansion to neighboring countries.

\section{Violence Has Skyrocketed in Mexico}

Mexico began experiencing a significant rise in violence and homicide rates during the presidency of Calderón, which was reminiscent of the violence in Colombia during the 1990s. Over 200,000 homicides have occurred since 2017, and the violence and homicide rates have mainly been attributed to drug trafficking organizations (Shirk \& Wallman, 2015, p. 1350). On December 1, 2006, former president Calderón was elected to the Mexican presidency and, within a short period, he launched México's war on drugs by deploying more than 6,500 Mexican soldiers to states like Michoacán to battle the cartels hitting the areas with violence. The massive deployment of the armed forces through former Mexican presidents was intended to quickly and decisively curtail the violence; however, it unintendedly aggravated the conflict. To some extent, the Mexican government's battle against its drug cartels demonstrates that Mexico may have had Colombia in mind (Haugaard, Isacson, \& Johnson, 2011, p. 3).

\section{The Kingpin Strategy in Mexico: An Ultimate Failure}

Drug trafficking in Mexico is not a new, recent phenomenon. Mexico's history with its drug war has repeatedly shown that there is little evidence to demonstrate or suggest that the 
kingpin strategy implemented by former Mexican presidents and modeled after the Colombian anti-cartel operations a decade earlier has been a successful model for Mexico's war on drugs. Also, it has consistently demonstrated that major cartels rarely survive long in the spotlight (Hamilton, 2013). Mexico has seen the rise and fall of many cartels as well as the continuous presence of major cartels such as the Sinaloa Cartel. The initial operation, in which the U.S. and Mexican governments targeted the top leaders of the Guadalajara Cartel in the late 1980s and early 1990s, has shown that the kingpin strategy is an ultimate failure because the arrests paved a path for the emergence of three cartels: Juárez, Sinaloa, and Tijuana (Shirk \& Wallman, 2015, p. 1357). The second event that demonstrates failure is in 1996 with the arrest of the Gulf Cartel leader, Juan García Ábrego. This event is a crucial example that demonstrates how there is an increase in violence within cartels after the loss of a leader because it opens the door for a "war of succession" as lieutenants vie to fill the vacant leadership position (Shirk \& Wallman, 2015, p. 1364); this occurred as Osiel Cárdenas Guillén, a "lieutenant" murdered his rivals and aimed to seize control. Furthermore, we saw history repeat itself in the early 2000s when the Tijuana Cartel lost its leader Benjamín Arellano Félix, and the Gulf Cartel lost Cárdenas Guillén. These arrests caused groups to splinter, establishing organizations: Los Zetas, La Familia Michoacana, and the Beltrán-Leyva Cartel. In the last decade, we continue seeing the splintering cycle, leading to the establishment of more organizations like the CJNG.

Altogether, there is a cycle that is sort of predictable with cartels - splinter off an existing cartel, staying low-profile for a while and then, as they become more independent, the cartel leaders decide to go for the big spotlight by making a spectacular introductory statement. In the end, when they get the full attention of the state, they get hit by it and flame out leaving a group 
to splinter and establish their organization. The implementation of the kingpin fight has led to aggravated consequences: violence increasing, destabilization of the drug cartel's power structures, and fragmentation (Shirk \& Wallman, 2015, p. 1364). Initially, two major cartels were controlling the drug trafficking organizations: the Guadalajara Cartel and the Gulf Cartel. Then, in 2007, there were five major cartels. By 2011, the number of Mexican cartels increased to sixteen, nine of them being dominant, well-established organizations (Shirk \& Wallman, 2015, p. 1365; Beittel, 2018, p. 10). In short, the number of cartels tripled and the violence rate spiraled out of control. Joaquín Guzmán, alias "El Chapo," had outlasted many of his peers and predecessors in the drug trafficking and war on drugs (Hamilton, 2013). Because of the structures that "El Chapo" and the Milenio Cartel, also known as the Cártel de los Valencia, left behind such as resources, intelligence, and network, they may have become key in the development of the CJNG. It can be asserted that "E1 Mencho" may follow "El Chapo's" footsteps to outlast. Unlike many of his flamboyant rivals who are known for collecting menageries of exotic pets or buying luxury cars; "El Mencho" has kept a low profile (McMichael, 2018).

\section{The New Issue: The CJNG is Mexico's Newest Threat}

Extensive media coverage has demonstrated the CJNG's illicit activities, such as being armed with rocket-propelled grenades to bring down a military helicopter. It can be argued that the media coverage and social media are strategies used to intensify the impact of the CJNG's operations (The Global Initiative, 2015). Altogether, the CJNG's regional and international reach have demonstrated how it has become Mexico's newest threat. 


\section{How Was the CJNG Formed?}

During Peña Nieto's Presidency, Mexico and the U.S. saw the capture of "El Chapo" along with high-profile leaders of Los Zetas and Knights Templar Cartel. However, as typically happens when any of Mexico's powerful cartels are weakened, another has since risen to prominence. The Sinaloa and Tamaulipas cartels began to lose control of organized crime in Tierra Caliente as a result of the continuous confrontations and years of aggressive pursuit by security forces, leading to the expansion of one of the independent cartels, the CJNG (Shirk \& Wallman, 2015, p. 135). It is crucial for the Mexican and U.S. government to turn their heads towards CJNG because "it is not just about the territories they are seizing; what has caught international attention is the way they operate" (The Global Initiative, 2015). Many of the fully developed Mexican cartels remain the greatest criminal drug threat to the U.S., and no other group is currently positioned to challenge them (DEA, 2018).

The emergence of the CJNG came after the death of Ignacio Coronel Villarreal, alias "Nacho," the Sinaloa Cartel's "lieutenant" in Jalisco, which unleashed a "war for succession" (La Rosa \& Shirk, 2018, p. 4). The CJNG managed to successfully establish and grow in large part because of its strong alliances with the Milenio Cartel (Pérez Caballero, 2014). Nemesio Oseguera Cervantes, alias "El Mencho," is considered the current leader of the CJNG and has become one of Mexico and the U.S.'s most wanted - with the U.S. Department of Justice recently offering a ten million dollar reward for information leading to his arrest (DEA, 2018). This prioritization to target and capture "El Mencho" in efforts to disrupt the CJNG has demonstrated that the emphasis on the use of the kingpin strategy still predominates. As history has 
demonstrated, there is little evidence that the implementation of the kingpin strategy will succeed this time, and if "El Mencho" does get arrested or killed, the results are predictable.

Since its emergence, the CJNG has rapidly grown and media has captured many of its deadly encounters with Mexican officials and their rival cartels. Early June, around the Michoacán regions of Tierra Caliente and Bajío, CJNG and Los Viagras' violent confrontations for control in the state left at least nine civilians dead (El Imparcial, 2019). The CJNG has become the foremost and greatest criminal drug threat in Mexico. Notwithstanding the fortunate geographical and economic characteristics of its strategic base, the CJNG's evolution from localized paramilitary faction into a transnational drug trafficking organization is the "result of a hybrid strategic formula" (Croft, 2015). The leadership of the CJNG by a Michoacán native-like "El Mencho," or his son Rubén Oseguera González, alias “El Menchito,” illustrates the powerbase left by the Milenio Cartel; the structures that the group left behind such as resources, intelligence, and networks have become key in the development of the CJNG (Pérez Caballero, 2018).

\section{How Do They Operate?}

Traditionally, emerging Mexican drug trafficking organizations seem to prefer low profile operations, leaving all the high profile action to more established cartels. In contrast, the CJNG openly challenges the authorities and other rival cartels. In late May, ten civilians in Uruapan, Michoacán were killed and four were left injured in a shootout between the CJNG and Los Viagras (Arrieta, 2019). Through these confrontations, the message that the CJNG wants its rivals and the government to receive is that "we're much more powerful and have more control 
and weaponry so don't mess with us" (Bonello, 2019). Both the cartel's messages and its battles are massive and somehow spectacular.

Initially, the CJNG began as an organization with its mission to battle Los Zetas and has moved to be heavily engaged in the production and distribution of methamphetamine (Mexican Investigative Team, 2018) Also, it is associated with the use of extreme violence against rivals and federal forces. The CJNG also "brands" itself as protectors of civilians in various states through the use of propaganda and the arrest of key figures has not helped to interrupt the CJNG's regional expansion. For instance, Victor Hugo Delgado Renteria, alias "El Tornado," was arrested in July 2013, while "El Menchito,” was arrested in January 2014 (O Neill Mccleskey, 2013; Wells, 2014). Despite the arrest of Oseguera González, thought to be the second-in-command of the cartel, the CJNG has extended its geographic reach and manage to maintain its cohesion while exploiting the splintering of the Sinaloa organization.

In regards to its regional expansion, the CJNG has a presence in 22 states throughout Mexico, which combined is nearly half of Mexico (DEA, 2018, p. 97). The high levels of violence that have hit Ciudad Juárez and Tijuana have resulted from the CJNG's expansion in which it has battled with the Sinaloa Cartel for control of the lucrative heroin trade and corresponding smuggling routes. Despite the capture of its top leaders, the CJNG has managed to resist fragmentation and continue its geographic expansion and scope of activities. On the one hand, the Sinaloa Cartel continues to maintain the most expansive footprint in the U.S., while on the other hand, the CJNG's domestic presence has significantly expanded in the past few years. Further, analysts have pointed out that the CJNG efforts to move towards an aggressive growth strategy have been possible because of the increasing demand for heroin and methamphetamine. 
Also, the CJNG's efforts to dominate critical ports such as of Veracruz, Manzanillo and Lázaro

Cárdenas on both the Pacific and Gulf Coasts have allowed it to consolidate essential components of the global narcotics supply chain. Because of its access to such ports, CJNG has managed to gain an international reach and get access to precursor chemicals that flow into Mexico from China, India and other parts of Latin America (Beittel, 2018, p. 23; Prates, 2011). In addition to its international reach, the CJNG has expanded its cocaine trafficking operations in Japan, Indonesia, and Hong Kong, suggesting it is well-positioned to be a powerful threat (The Global Initiative, 2015).

\section{Efforts to Keep Their Position in the Competitive and Ever-changing Environment of Mexico's Drug Trade?}

According to Jesús Pérez Caballero, a conacyt researcher on organized crime, drug trafficking and criminal law in Latin America, the CJNG has continued to adapt to the changing environment by adopting a regional strategy, rather than expanding across the country; "its links with Jalisco help explain its success" (Pérez Caballero, 2014). For example, Jalisco has experienced the presence of major cartels like the Guadalajara, Sinaloa, and Milenio, therefore, this suggests resources, network and intelligence essential for the financial structures such as local know-how on money laundering and frontmen, all of which the CJNG has taken the opportunity to take advantage of (La Rosa \& Shirk, 2018, p. 18-19). Pérez Caballero states, "The fact that the CJNG is still growing highlights its adaptability, and willingness to adopt a vigilante discourse when necessary" (Pérez Caballero, 2014).

Further, Pérez Caballero points out that the CJNG's regional strategy is accompanied "by using violence in diverse ways that are naturally integrated with its objectives" as they are not afraid to confront both rivals and the state (Pérez Caballero, 2014). Violence has allowed the 
CJNG to expand and demonstrate its ability to adopt authorities' narratives. For instance, the CJNG initially offered its "Mata Zetas" to go against the Zetas and offered their "Mata-templarios" to battle the Knights Templar (Eells, 2017). Furthermore, it is assumed that the CJNG purchased training from the FARC and Guatemalan guerrillas and using tactics such as improvised explosive devices (IED) or "potato bombs" (Jones, 2019, p. 19; Álvarez, 2018; La Rosa \& Shirk, 2018,p. 13). The CJNG's high profile approach and defying the state could become counter-productive if and when the state flames them out, as the demise of prior major cartels has proved.

\section{What Fails to be Done and What Needs to Be Done?}

It is clear that the CJNG and Mexico's other cartels are a serious threat to Mexican public security. However, the CJNG as a new threat is the result of long-term, complex and unresolved issues that require serious and sustained attention by the Mexican and U.S. governments. Throughout the last two decades, the US and Mexico have invested billions of dollars in the kingpin strategy (McMichael, 2018), despite history demonstrating that it is an ultimate fail by causing cartels to splinter and violence rates to reach all-time high. The kingpin strategy has done little to address Mexico's real problems of insecurity and violence. With a continued emphasis on the kingpin strategy, the outcomes are predictable - greater violence and the eventual emergence of new powerful organizations. Therefore, the U.S. and Mexican governments should not consider continuing with the implementation of the kingpin strategy. The battle against the CJNG demands various strategies that take into account the factor that contributes to the CJNG's success: influence, illicit activities, violence, and financial structure, 
and as Evelyn Krache Morris puts it: "We Need to Hit Them Where It Hurts: the Wallet" because "as in any business, money is the fuel that keeps the cartels running" (Morris, 2013).

Apart from the consequences of the kingpin strategy, there have been abuses of power and human rights violations. According to Haugaard, Isacson, \& Johnson, Mexico's National Human Rights Commission received over 4,700 reports of human rights-related complaints committed by military officials and there has also been little success in obtaining convictions due to a lack of resources and a weak judicial system (Haugaard, Isacson, \& Johnson, 2011, p. 4). Further, the Mexican government has had little success in apprehending and obtaining sentences against drug cartel members, especially those in the CJNG (Alzaga, 2018). As Haugaard, Isacson, \& Johnson suggest, the population needs to become Mexico's top priority and provide resources and protection (Haugaard, Isacson, \& Johnson, 2011, p. 25).

The challenge is extremely complex and serious, and sustained intelligence work will be needed. Strong institutions are essential, but it will be challenging as well in a country widely infested with violence and corruption (Bunker, 2015). Clara McMichael, a New York-based journalist who covers foreign policy, social justice, crime and immigration in the U.S. and Latin America, points out that experts say "changes must occur on a broad structural level to reduce violence in Mexico, and these alternatives to the kingpin strategy would be complex and slower to achieve" (McMichael, 2018). The alternatives would include holistic approaches like tackling corruption, fighting poverty that often forces people to contribute to drug trafficking, providing well-paid employment opportunities, and the U.S. increasing its efforts to curtail demand for drugs. Overall, the efforts to solve Mexico's situation will need to involve the development of 
various strategies because one standardized approach will not be enough nor appropriate to target every issue Mexico currently faces and the aspects that are allowing the CJNG to succeed. 


\section{References}

Álvarez, C. (2018). El CJNG contrató ex guerrilleros colombianos, afirma gobernador de Jalisco; Seido protege al Cártel: Loret. Retrieved from https://zetatijuana.com/2018/05/el-cjng-contrato-ex-guerrilleros-colombianos-afirma-gob ernador-de-jalisco-seido-protege-al-cartel-loret/

Alzaga, I. (2018). La PGR, sin condenas contra cártel de Jalisco. Retrieved from https://www.milenio.com/policia/la-pgr-sin-condenas-contra-cartel-de-jalisco

Arrieta, C. (2019). Enfrentamiento entre cárteles deja 9 muertos y cuatro lesionados en Uruapan, Michoacán. Retrieved from https://www.eluniversal.com.mx/estados/enfrentamiento-deja-9-muertos-y-cuatro-lesiona dos-en-uruapan-michoacan

Asmann, P. (2018). Are Armed Drones the Weapon of the Future for Mexico's Cartels? Retrieved from https://www.insightcrime.org/news/brief/armed-drones-weapon-future-mexico-cartels/

Beittel, J. S. (2018). Mexico: Organized Crime and Drug Trafficking Organizations. Washington, DC: Congressional Research Service. Retrieved from https://fas.org/sgp/crs/row/R41576.pdf

Bonello, D. (2019). One of Mexico's Biggest Cartels Is Trying to Expand in Frightening Ways. Retrieved from https://www.vice.com/en_us/article/evy5wj/how-one-of-mexicos-biggest-cartels-is-trying -to-dominate-in-mexicos-wildest-west

Bunker, K. A. (2015). Old and New Governmental-Criminal Relationships In Mexico: A Historical Analysis of the Illicit Political Economy and Effects On State Sovereignty. Retrieved from https://smallwarsjournal.com/jrnl/art/old-and-new-governmental-criminal-relationships-i n-mexico-a-historical-analysis-of-the-illi

Chepesiuk, R. (2003). The bullet or the bribe: Taking down Colombia's Cali drug Cartel. Westport, Conn.: Praeger.

Croft, H. (2015). Operation Jalisco: The Rise of The Jalisco New Generation Cartel and Peña Nieto's Militarised Security Strategy. Retrieved from https://smallwarsjournal.com/jrnl/art/operation-jalisco-the-rise-of-the-jalisco-new-generat ion-cartel-and-peña-nieto's-militarise

DEA. (2018). 2018 National Drug Threat Assessment. Retrieved from https://www.dea.gov/press-releases/2018/11/02/dea-releases-2018-national-drug-threat-as sessment-0

DEA. (2018). Justice, Treasury, and State Departments announce coordinated enforcement efforts against Cartel Jalisco Nueva Generacion. United States Drug Enforcement Administration. Retrieved from 
https://www.dea.gov/press-releases/2018/10/16/justice-treasury-and-state-departments-an nounce-coordinated-enforcement

Eells, J. (2017). The Brutal Rise of El Mencho. Retrieved from

https://www.rollingstone.com/culture/culture-features/the-brutal-rise-of-el-mencho-1969 $\underline{80 /}$

El Imparcial. (2019). Michoacán: 9 muertos tras guerra entre CJNG y Los Viagras.

Retrieved from

https://www.elimparcial.com/mexico/Michoacan-9-muertos-tras-guerra-entre-CJNG-y-L os-Viagras-20190608-0004.ht

Escalante Gonzalbo, F. (2009). ¿Puede México ser Colombia? Violencia, narcotráfico y Estado. Nueva Sociedad, No. 220, 84-96. Retrieved from https://nuso.org/media/articles/downloads/3595_1.pdf.

Hamilton, K. (2013). Why Killing Kingpins Won't Stop Mexico's Drug Cartels. Retrieved from https://www.theatlantic.com/international/archive/2013/02/why-killing-kingpins-wont-sto p-mexicos-drug-cartels/273558/

Haugaard, L., Isacson, A., \& Johnson, J. (2011). A Cautionary Tale: Lessons of Plan Colombia for Mexico and Beyond. Retrieved from https://www.lawg.org/a-cautionary-tale-lessons-of-plan-colombia-for-mexico-and-beyon d/

Jones, N. (2019). Bacterial Conjugation as a Framework for the Homogenization of Tactics in Mexican Organized Crime. Studies in Conflict \& Terrorism, 1-30.

Jones, N. (2018). The Strategic Implications of the Cártel de Jalisco Nueva Generación. Journal of Strategic Security, 11(1), 19-42. Retrieved from https://www-jstor-org.proxy.lib.pdx.edu/stable/26466904

Keefe, P. R. (2012). Cocaine Incorporated. Retrieved from https://www.nytimes.com/2012/06/17/magazine/how-a-mexican-drug-cartel-makes-its-bi $\underline{\text { llions.html }}$

Kellner, Tomas, \& Pipitone, Francesco. (2010). Inside Mexico's drug war. World Policy Journal, 27(1), 29-37.

La Rosa, L., \& Shirk, D. A. (2018). The New Generation: Mexico's Emerging Organized Crime Threat. Justice in Mexico. Retrieved from https://justiceinmexico.org/wp-content/uploads/2018/03/180319-Policy_Brief-CJNG.pdf

Lee, B., Renwick, D., \& Labrador, R. C. (2019). Mexico's Drug War. Retrieved from https://www.cfr.org/backgrounder/mexicos-drug-war

McMichael, C.W. (2018). Mexico’s kingpin strategy: A costly failure. Global Comment. Retrieved from http://globalcomment.com/mexicos-kingpin-strategy-a-costly-failure/

Mexican Investigative Team. (2018). The New Criminal Group Hitting Mexico's CJNG 
Where It Hurts. Retrieved from

https://www.insightcrime.org/news/analysis/new-criminal-group-hitting-mexicos-cjng-hu $\underline{\mathrm{rts} /}$

Morris, E. K. (2013). Think Again: Mexican Drug Cartels. Foreign Policy,(203), 30-33. https://foreignpolicy.com/2013/12/04/think-again-mexican-drug-cartels/

O Neill Mccleskey, C. (2013). New Generation Jalisco Cartel Leader Captured In Mexico. Retrieved from

https://www.insightcrime.org/news/brief/new-generation-jalisco-cartel-leader-captured-in -guadalajara/

Pérez Caballero, J. (2014) How the Jalisco Cartel Evolved with Mexico's Drug War. InSight Crime. Retrieved from https://www.insightcrime.org/news/analysis/jalisco-cartel-evolved-mexico-war-drugs/

Pérez Caballero, J. (2018). Mexico’s CJNG: Local Consolidation, Military Expansion and Vigilante Rhetoric. InSight Crime. Retrieved from https://www.insightcrime.org/news/analysis/mexico-cjng-local-consolidation-military-ex pansion-vigilante-rhetoric/

Prates, V. (2011). Mexico Seizes 18 Tons Meth Chemicals Shipped from India. Retrieved from https://www.insightcrime.org/news/brief/mexico-seizes-18-tons-meth-chemicals-shippedfrom-india/

Shirk, D. and Wallman, J. (2015). 'Understanding Mexico's Drug Violence'. Journal of Conflict Resolution, 59(8), pp.1348-1376.

The Global Initiative. (2015). The Jalisco Cartel: Mexico's New Menace. Retrieved from https://globalinitiative.net/the-cartel-jalisco-nueva-generacion-mexicos-new-menace/

Thomet, L. (2015). New Generation cartel Mexico's latest menace. Yahoo News. Retrieved from https://news.yahoo.com/generation-cartel-mexicos-latest-menace-210547540.html

Wells, M. (2014). Mexico Captures CJNG Leader, Investigates Links With Vigilantes. Retrieved from https://www.insightcrime.org/news/brief/mexico-captures-cjng-leader-investigates-linkswith-vigilantes/ 